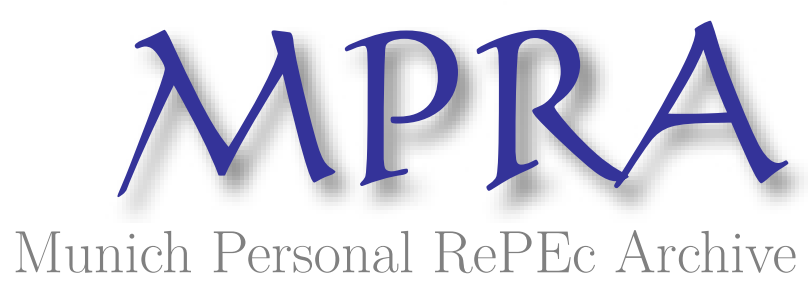

\title{
Enemy of Labour? Analysing the Employment Effects of Mergers and Acquisitions
}

Lehto, Eero and Böckerman, Petri

Labour Institute for Economic Research

15 October 2006

Online at https://mpra.ub.uni-muenchen.de/1812/

MPRA Paper No. 1812, posted 16 Feb 2007 UTC 


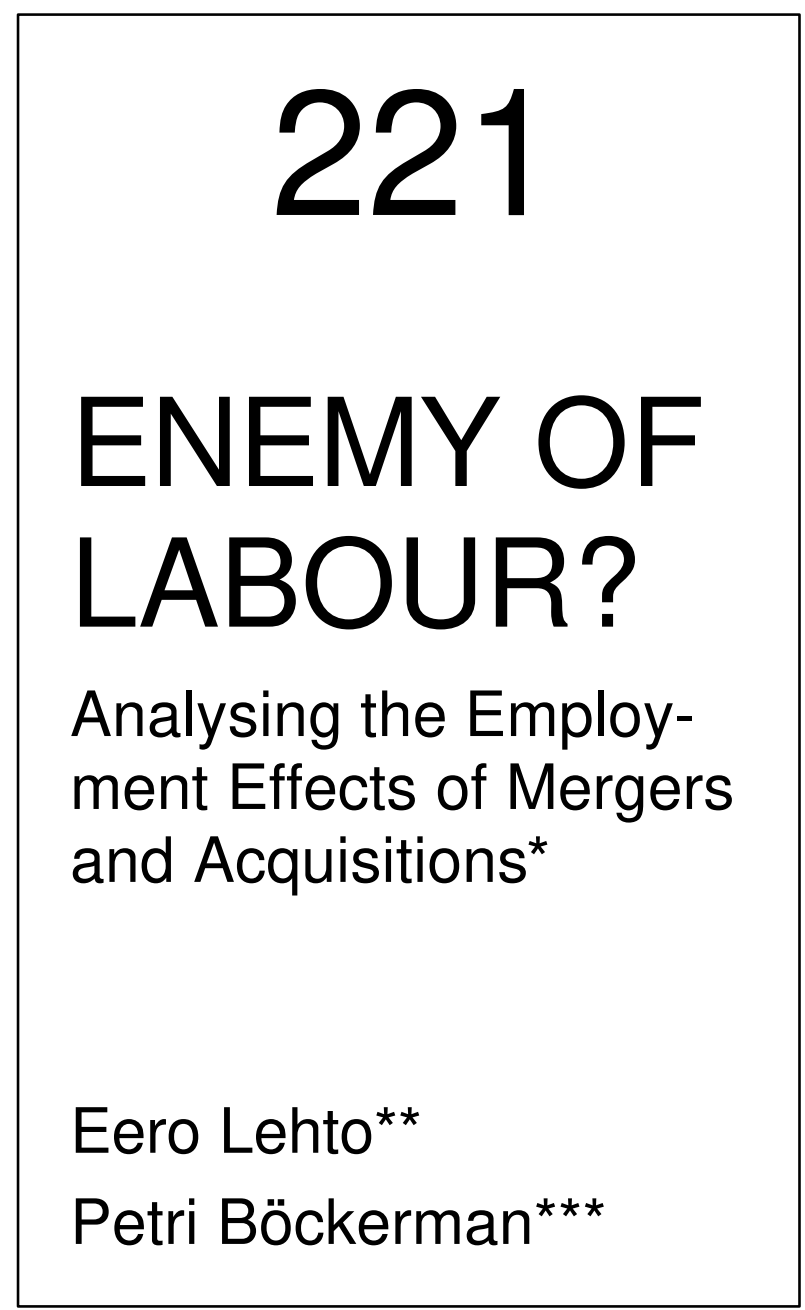

* We are grateful to the Finnish Metalworkers' Union and the Finnish Association of Graduate Engineers for financial support. The matched data that is used to produce the results reported in this paper can be accessed on site at the Research Laboratory of the Business Structures Unit of Statistics Finland. We are grateful to Mika Maliranta for comments. Paul A. Dillingham has kindly checked the language. The usual disclaimer applies.

** Labour Institute for Economic Research.

*** Corresponding author. Labour Institute for Economic Research. Address: Pitkänsillanranta 3A, 6. krs. FIN-00530 Helsinki, FINLAND. Phone: +358-9-25357330. Fax: +358-9-25357332. Emails: eero.lehto@labour.fi and petri.bockerman@labour.fi 
ISBN 952-209-028-X

ISSN 1795-1801 


\title{
TIIVISTELMÄ
}

Tutkimuksessa tarkastellaan yrityskauppojen työllisyysvaikutuksia käyttäen yhdistettyä aineistoa vuosilta 1989-2003. Aineisto kattaa kaikki sektorit. Vertaamme kansainvälisten yrityskauppojen vaikutuksia sekä kotimaisiin yrityskauppoihin että yritysten sisäisiin rakennejärjestelyihin. Tulosten valossa kansainväliset yrityskaupat vähentävät työllisyyttä teollisuudessa. Kansainvälisten yrityskauppojen vaikutukset ovat muilla toimialoilla huomattavasti heikompia. Kotimaiset yrityskaupat ja yritysten sisäiset rakennejärjestelyt johtavat myös tyypillisesti työllisyyden heikkemiseen, mutta vaikutukset vaihtelevat sektoreittain.

\begin{abstract}
This paper analyses the employment effects of mergers and acquisitions (M\&As) by using matched establishment-level data from Finland over the period 1989-2003. The data covers all sectors. We compare the employment effects of cross-border M\&As with the effects arising from two different types of domestic M\&As and internal restructurings. The results reveal that cross-border M\&As lead to downsizing in manufacturing employment. The effects of cross-border M\&As on employment in nonmanufacturing are much weaker. Changes in ownership associated with domestic M\&As and internal restructurings also typically cause employment losses, but they exhibit an interesting sectoral variation.
\end{abstract}

JEL Codes: G34, J23, L23

Key words: mergers and acquisitions, M\&As, takeovers, employment, workforce 


\section{INTRODUCTION}

This paper analyses the effect of mergers and acquisitions (M\&As) on the employment of firms' establishments in Finland. M\&As are a key device to enlarge a purchasing firm in all developed countries. For instance, in Finland, hardly any significant restructuring of any industry has been carried out without ownership changes. In most countries M\&As have developed in a procyclical manner. There is no upward trend in the frequency of domestic M\&As. In contrast, the volume of cross-border M\&As has started to increase at a rapid pace recently. Cross-border M\&As represent an important part of the globalisation of business in many different industries. They have spread from the manufacturing to the service industries. Rossi and Volpin (2003) estimate that crossborder M\&As cover roughly a quarter of the total M\&A activity nowadays. This evolution has inspired a lot of debate in European countries. In general, the attitude towards M\&As has been rather positive, because they restructure the economy. Despite this, cross-border M\&As, especially, have been seen, in public debate, as a threat to employment.

Systematic micro-level evidence on the causal effect of different types of M\&As on employment is still quite sparse despite the obvious importance of the topic. For instance, economic literature on multinational companies has mostly analysed the potential effects of foreign acquisitions on productivity and wages (e.g. Bellak, 2004). This paper contributes to the literature by analysing the employment effects of M\&As on target firms by using matched establishment-level data from Finland over the period 1989-2003. In this paper, we do not focus solely on cross-border or domestic M\&As, but we analyse the employment effects of several different types of M\&As. We classify M\&As as being either a cross-border M\&A (in which the purchaser is a foreign company that is located abroad), a domestic M\&A with a domestically-owned purchaser, a domestic M\&A with a foreign-owned company that is located in Finland or an internal restructuring in which the purchaser is not another company. Most of the earlier research studies have used relatively small samples of companies, making it hard to generalize the results obtained. The use of comprehensive data on several different types of M\&As puts us in a somewhat better position to analyse the issue at hand.

The Finnish case is interesting from the perspective of cross-border M\&As and the domestic M\&As with foreign ownership. Since Finland is a small open country, the 
enlargement of foreign ownership can have a more profound effect on employment in Finland than in large countries. These issues have been a subject of public debate in Finland recently owing to the fact that cross-border M\&As have greatly increased in number during the late 1990s, following the lift of restrictions over foreign-ownership during the early 1990s. ${ }^{1}$ Since foreign firms have settled down by establishing a Finnish affiliate, they have typically continued to enlarge through domestic M\&As, especially in many service industries, like transport and various other business activities.

Our paper deviates from most of the earlier papers in this strand of research regarding the data coverage, the definition of M\&As and the methods that are used to analyse the effect of M\&As on employment. Most of the earlier papers have focused on manufacturing, mainly owing to the availability of data sources. This is important, because the share of manufacturing has declined in almost all developed countries over the past few decades. This applies to Finland. We use data that also includes services. In particular, the dynamics of employment may be different between these industries, because services are less capital-intensive than manufacturing. Hence, it is interesting to analyse the effect of M\&As on employment separately in the manufacturing sector and in the service sector. It may well be that conclusions obtained in the earlier studies of this strand of research at least partly reflect partly their focus, which is primarily on the manufacturing sector.

Regarding the definition of M\&As, we use detailed information on the actual events of different types of M\&As. ${ }^{2}$ For example, the interference of foreign firms and foreign ownership is then more accurately specified than in the studies which consider a registered change from domestic to foreign majority ownership. From the methodological perspective, most of the earlier papers on the topic (e.g. Conyon et al. 2002b; Gugler and Yurtoglu, 2004) have relied solely on traditional parametric methods to identify the effect of M\&As on employment. In contrast, we use non-parametric, matching methods to pursue the issue at hand. Our data enables us to ensure that the control group to whom the establishments - which have been targets of different types of M\&As - are compared with include only such establishments that have not been

\footnotetext{
${ }^{1}$ Lovio (2004) provides an overview of the globalisation of Finnish corporations.

${ }^{2}$ Our data does not permit us to separate friendly and hostile takeovers from each other, which has been possible in some other papers (e.g. Conyon et al. 2002b).
} 
involved in any kind of M\&As. This allows us to isolate the pure effects of several different types of M\&As on employment.

In this paper, we discover that cross-border M\&As lead to downsizing in manufacturing employment. The effects of cross-border M\&As on employment in non-manufacturing are much weaker. Domestic M\&As with a domestic purchaser, instead, have negative employment effects for all sectors. The impact of domestic M\&As with foreign-owned purchasers is remarkably negative in construction and other services. In addition, internal restructurings have negative employment effects in trade (including hotels and restaurants). Taken together, our most important empirical finding is that almost all changes in ownership lead to employment losses. That cross-border M\&As had a negative impact only in manufacturing and that domestic M\&As with foreign-owned purchasers had, however, a substantial negative impact on employment in construction and other services may emerge from the situation in which foreign interference in service industries develops in two stages: first to establish a bridgehead through a crossborder M\&A and, after this, to strengthen the dominance of the market through domestic M\&As. Apparently, the deep-going rationalisation of activities is typical only of the latter stage, because deeper knowledge of the market has developed for a foreign player.

The paper proceeds as follows. Section 2 contains a survey of the earlier empirical literature that has analysed the effects of M\&As on employment. By a wide margin, most of the available empirical evidence originates from the USA or the UK. Other countries are not well covered. Section 3 discusses the most important theoretical arguments regarding the effect of M\&As on employment. Section 4 contains a description of our matched establishment-level data that is used to address the issue at hand. Section 5 describes the empirical framework that is used to analyse the effect of M\&As on employment. Section 6 reports our estimation results. The last section concludes. 


\section{RELEVANT EMPIRICAL LITERATURE}

Brown and Medoff (1988), Bhagat et al. (1990), Lichtenberg and Siegel (1990) report negative effects of M\&As on employment in the USA. In contrast, McGuckin et al. (1995) and McGuckin and Nguyen (2000) discover some positive effects of M\&As on employment in the manufacturing sector, in particular, at the plant level in the USA. In addition, Ollinger et al. (2005) report that there have not been negative effects of M\&As on employment in the food industry over the period 1977-1987. It is important to note that part of the evidence is based on very restricted samples of companies covering narrow segments of the US economy. For instance, Brown and Medoff (1988) obtain their estimates on the effect of M\&As on employment from a sample of companies located in the state of Michigan for the period 1978-1984. This may be the reason for somewhat mixed results on the employment effects of M\&As that have emerged from the USA.

UK companies have been subjects of substantial takeover activity for long time. For that reason, they represent an interesting opportunity to investigate the effects of M\&As on subsequent employment. Conyon et al. (2000a, 2000b, 2000c) report the negative effects of M\&As on employment in the UK by using data on 277 listed companies over the period 1967-1996. Interestingly, the negative effects on employment are particularly pronounced for related and hostile transactions. Girma and Görg (2004) discover by using data from the UK electronics industry for the period 1980-1993 that the incidence of foreign takeover reduces the employment growth of a domestic establishment, in particular for unskilled labour. Hence, cross-border M\&As have some effects on the determination of skill-mix in companies.

In addition to evidence that stems from US and UK studies, there is some empirical evidence from other European countries. For instance, Piscitello and Rabbiosi (2002) discover by using Italian firm-level data over the 1990s that, compared with firms that were not subject to any ownership change, companies targeted by foreign investors marked an increase in both labour productivity and the employment level a few years after the acquisition. This result holds especially if the target firm is a small firm and if the investor is a European multinational company. 
For Sweden, which is a small open economy much like Finland, Siegel and Simons (2006) report by using linked employer-employee data of manufacturing companies over the period 1985-1998 that M\&As lead to improvements in firm performance and plant productivity, although they also result in the downsizing of establishments and firms in terms of employment. However, their linked employer-employee data do not include cross-border M\&As separately. Hence, they are not able to compare the employment effects of different types of M\&As (cross-border M\&As vs. domestic M\&As). In addition, they base their identification of M\&As on changes in plant codes by Statistics Sweden, not on the records regarding the actual events of M\&As.

Comparison of US and European experiences regarding M\&As provides an interesting perspective on the issue. Gugler and Yurtoglu (2004) study the effect of M\&As on employment in Europe and the USA by using merger data for the USA that begin in the late 1970s, for other countries in the mid-80s. They use dynamic GMM models in order to produce results and they provide a brief comparison of the employment effects of cross-border and domestic M\&As. Gugler and Yurtoglu (2004) do not find any adverse effects of M\&As on labour demand in the USA that have been reported in some of the earlier studies. However, there is the prevalence of the negative effect on employment in Europe. The quantitative magnitude of the effect of M\&As on employment is substantial in Europe, because Gugler and Yurtoglu (2004) document that European mergers reduce the demand for labour by about $10 \%$ on average. Gugler and Yurtoglu (2004) attribute this to more rigid labour markets in Europe than in the USA. For that reason companies are forced to use M\&As in Europe as a restructuring device.

There are some earlier empirical studies on the effects of foreign acquisitions, using Finnish data. All these papers have used linked employer-employee data covering solely the manufacturing sector. In addition, the available studies consider either productivity effects (Ilmakunnas and Maliranta, 2004; Maliranta, 2005) or wage and education effects (Huttunen, 2006). In particular, Huttunen (2006) reports that the share of highly educated workers of the total workforce declines, although slightly and slowly, after the ownership has changed from domestic to foreign in the acquired plants. ${ }^{3}$

\footnotetext{
${ }^{3}$ Foreign acquisition is defined in Huttunen's (2006) paper based on the share of foreign-ownership as being over 20 per cent. We use data on the actual events of different types of M\&As, instead.
} 


\section{THEORETICAL CONSIDERATIONS}

To recognize the motives for M\&As helps us to understand how M\&As influence employment. The most important motives of M\&As (e.g. Mueller, 2003) are to
1) obtain genuine synergy gains (Farrell and Shapiro, 1990);
2) utilize scales economies in various forms;
3) strengthen the market power in pricing;
4) revise the implicit agreements related to the firm's personnel and other stake holders; and
5) promote the managers' own deviating interests.

An M\&A creates synergy gains when the more efficient modes of actions in either an acquiring or in an acquired firm are extended to comprise the whole enlarged firm. In horizontal M\&As the marginal costs of production in an inefficient firm typically lower to the level which prevails in the more efficient party of an M\&A. In vertical M\&As the mechanism may be different. An M\&A may then intensify incentives to exert effort in various activities, for example, in the commercialization of innovations, as suggested by the empirical findings of Lehto and Lehtoranta (2004) and Lehto (2006). It is clear that synergy-promoting M\&As primarily increase productivity. These types of M\&As may also support employment of the acquiring and the target company. The reason is that by raising efficiency, the parties of M\&As become more competitive, which may help them to take over the market from their competitors.

It is not, however, evident that M\&As, in general, only tend to internalize the benefits of genuine synergy gains abstracted from the utilization of scale economics. It is plausible that the parties of M\&As often aim to jointly use the assets (including human capital) which the new parent firm possesses after the merger. ${ }^{4}$ Sharing assets in this way is motivated by the cost savings obtained. The downsizing of overlapping activities in this process almost always involves reductions of the workforce.

By definition, M\&As decrease the number of independent players, which concentrates the market. Salant et al. (1983), and Perry and Porter (1985) have shown that it does not pay to purchase another firm in order to decrease competition and to gain pricing power

\footnotetext{
${ }^{4}$ Markusen ( 2002) has put forward these ideas in the context of multinational firms.
} 
in the standard Cournot competition. However, when deviating from the Cournot framework, the positive effect of decreasing the number of players on profits is, in any case, present in horizontal M\&As. Therefore, the tendency to internalise the strengthened market power by higher prices will be part of horizontal mergers and acquisitions, and one can expect that, for this part, M\&As will reduce the scale of production and labour input, too.

Shleifer and Summers (1987) have strongly argued that the change in control associated with, especially, hostile M\&As offers an opportunity for a new management team to renege on implicit and explicit labour contracts that typically constitute obstacles to layoffs. In particular, implicit labour contracts are often used in order to encourage firmspecific investments (e.g. Malcomson, 1997). They are binding actions by the old owners of the company and the old management team. However, the new management team that is put in place after an M\&A is able to renege on implicit labour contracts and to reduce the number of the workforce. It is important to note that in Finland collective labour agreements are also binding on all foreign owners. Hence, it is only possible to renege on implicit labour contracts.

The idea that the managers of firms engage in "empire building" has long been regarded as one possible explanation for M\&As (Schumpeter, 1934; Marris, 1963). The managers are also considered to deviate from the owner's interests when they use "free cash" to undertake other firms, as hypothised by Jensen (1986). If these motives have any influence, they suggest a negative influence on the purchasing firm's profits but, regarding the impact on the employment, the forecast is unclear. It is plausible that the manager's behaviour is contingent on the requirements and values that vary in time. Nowadays, when the managers' success is increasingly evaluated through various efficiency measures, the tendency to become bigger has lost a lot of its endearment.

The effect of M\&As on employment may be contingent on the type of M\&As. The factors that matter are distance between the target and acquiring firm (domestic or foreign in our study);

i) the nationality of the

ii) the acquiring firm (domestic or foreign); and

iii) the institutional nature of an acquirer (another firm or another form of M\&A). 
Despite the fact that there are convincing arguments for expecting a decline in the amount of the workforce after an M\&A, it is important to recognize that the effect of M\&As on employment is not always necessarily negative. For instance, according to the traditional theory of multinational companies that is known as the so-called OLI paradigm (e.g. Markusen, 2002), a multinational company brings with it certain intangible asset, which gives it a competitive edge over domestic firms. ${ }^{5}$ In this case a multinational company and a cross-border M\&A as well as a domestic M\&A with a foreign-owned firm may well increase its workforce in the target country, taken that it is able to increase its market share vis-à-vis its domestic competitors. This scenario may occur in the service industries, where widely known brands, for instance, are important for the success of the company.

Asymmetry of information is able to explain why an M\&A's impact is contingent on its type. Previous research on the motives of M\&As has discovered that information on the target firm may become more incomplete when the distance between the purchasing firm and the target firm increases (Lehto, 2006). The asymmetric information then explains why most purchasers are located fairly close to targets. If remote purchasers are excluded, this phenomenon may not be relevant as regards the effects of M\&As. But if, after all, the nearby purchasers have, on average, more precise information about the target firms and their market than distant purchasers, this may be relevant for the effects of M\&As, too. It is illustrative that in the largest and in the deepest going M\&As in Finland the purchaser has always been domestic. This especially concerns large combination mergers in which several firms have merged into a single large firm so that each party of the merger is (in our data) considered as being a target firm in turn. It looks as if the better touch of the local markets has made it possible for profound rationalisation. From this, one may derive a hypothesis that radical structural reforms with considerable negative effects on employment are rather characterized by domestic M\&As and, perhaps, internal restructurings than cross-border M\&As.

On the other hand, one can argue that for foreign owners it may be easier to loosen themselves from implicit contracts that preserve employment in order to maximize the short-run profits. For this, one may expect that cross-border M\&As or domestic M\&As - in which the purchasing firm is foreign-owned - may cause a greater negative impact

\footnotetext{
${ }^{5}$ OLI is the abbreviation for "ownership-location-internationalisation".
} 
on employment than other domestic M\&As and internal restructurings. Casual Finnish evidence suggests that this is not a totally unlikely scenario, because foreign owners do not usually have respect for local interests regarding employment or labour standards that are often set well above the minimum standards that have been agreed upon in collective labour agreements.

To sum up, the theoretical discussion does not give a clear prediction about the effects of different types of M\&As on employment. Hence, the net effect of M\&As on employment is an empirical matter. The negative effect seems, however, to be the most likely. Indeed, most authors in this strand of research take the position that M\&As cause negative effects on employment over time (e.g. Conyon et al. 2002b). In addition, most of the earlier empirical investigations in this strand of research have reported statistically significant negative effects, especially for European countries (e.g. Gugler and Yurtoglu, 2004).

We explore the effect of M\&As on employment in three different industry blocks, which are
a) manufacturing (including utility industries);
b) construction and other services; and
c) trade (including hotels and restaurants).

Manufacturing is largely global by nature, from which it follows that foreign firms are equally present in the relevant market as domestic firms are. Owing to this, in manufacturing the opportunities to benefit from the restriction of competition can be considered as being scarce in all types of M\&As. In the service industries a domestic purchaser, being located in the same relevant market as the target firm, may have a greater interest than a foreign purchaser to buy another firm in order to limit competition. This especially concerns trade. Because the service market is often geographically restricted and because the joint use of assets may encounter geographical limits, as suggested by the findings in Lehto (2006), we hypothise that in the service sectors rationalisation through asset sharing and the related downsizing of employment is more typical of domestic M\&As (and internal restructuring) than of cross-border M\&As. To conclude, we expect that in the service industries and in construction, domestic M\&As (in which a purchaser can also be foreign-owned) and internal 
restructurings have a larger negative impact on employment than cross-border M\&As. Such a difference is not expected in manufacturing.

\section{THE DATA}

Our data on M\&As originates from the magazine Talouselämä, which is published on a weekly basis. M\&As are defined based on an ownership share of at least $50 \%$. The magazine reports all M\&As in which either the acquiring or the acquired firm is a Finnish one, or in which either the acquiring or the acquired firm is owned by a Finnish company. The magazine covers all sectors. The only major restriction is that the magazine Talouselämä does not keep a record of M\&As in which either the acquirer's or the target's turnover is less than FIM 3 million (or around 510000 Euros). In addition, we have omitted from the analysis those firms that have been targets of M\&As two (or more) times within a single year in order to avoid conflating the effects of different types of M\&As on employment. The number of those cases is very small, however. The whole analysis is done at the establishment level, because different establishments that belong to the same firm may perform differently. In addition, in some cases only a certain establishment, not the whole firm, is purchased. Hence, we have linked firms that have been subjects of M\&As according to the magazine Talouselämä to their establishments.

The data allows us to separate four different types of M\&As. These are cross-border M\&As, domestic M\&As with domestically-owned purchasers, domestic M\&As with foreign-owned purchasers and internal restructurings. Their exact definitions are given in Table 1. "Domestic" refers to a firm that is domestically located. A domestically located firm can then be either domestically-owned or foreign-owned. Hence, in this classification "foreign" has a dual meaning: firstly, it refers to the distance between the acquirer and the target firm and, secondly, it specifies the nationality of an acquirer's owners from the target firm's viewpoint. We classify internal restructuring into its own category, because we think that this type of M\&A may differ from others, because restructuring without the presence of another firm lacks some potential for synergy gains but may favour closer knowledge of the target firm's internal potential to renew. 
Table 1. Description of the variables

\begin{tabular}{l}
\hline \multicolumn{1}{c}{ Variables } \\
Types of M\&As: \\
Cross-border M\&A \\
Domestic M\&A (Domestic owner, located \\
in Finland)
\end{tabular}

Domestic M\&A (Foreign owner, located in Finland)

Internal restructuring

Establishment-level features:

Employment

The size of establishment

Firm's age

Exporter

Share of highly educated (technical)

Share of highly educated (other degrees)

Share of employees with intermediate degrees

Indicators:

Firm's legal form

Years

Regions

Industries

Definition/measurement

Cross-border M\&As are defined as cases where the acquiring firm is foreign. "Foreign" here means that the firm, which is reported by the magazine Talouselämä to be the acquirer, is not located in Finland at the time of the M\&A. (Source: the magazine Talouselämä)

We separate two types of domestic M\&As based on ownership. (These types are added together in Figs. 1-2). First, there are domestic M\&As, where the acquirer is domestically-owned and located in Finland.) (Source: the magazine Talouselämä)

Second, there are domestic M\&As, where the acquirer is foreign-owned, but located in Finland. (Hence, cross-border M\&As are defined as cases where transaction truly occurs across national borders.) (Source: the magazine Talouselämä)

Internal restructurings involve cases of transformation of a firm's organizational form without the involvement of another company. For instance, management buy-outs that have been popular through the 1990s and a smaller number of cases where an individual Finnish investor is buying the firm belong to this category of M\&As. (Source: the magazine Talouselämä)

A logarithm of the average number of employed persons in the establishment during the year. (Source: Business Register by SF)

A logarithm of the number of employed persons. (Source: Business Register by SF)

The age of a firm is measured in years. (Source: Business Register by SF)

Firm is involved in export activity $=1$, otherwise 0. (Source: Business Register by SF)

The share of highly educated employees with technical qualifications of the total number of employees in an establishment. (Source:

Employment Statistics by SF)

The share of highly educated employees (excluding the number of highly educated employees with technical qualifications) of the total number of employees in an establishment. (Source: Employment Statistics by SF) The share of employees with middle education in an establishment. Reference group for the education structure is made of those with comprehensive education only. (Source: Employment Statistics by SF)

Legal form of firm consists of following categories: corporation, general partnership, co-operative society and trader. (Source: Business Register by SF)

15-1 (The temporal variation of different types of M\&As is shown in Fig. 1.)

85 regional dummies based on NUTS 4 regions stipulated by the European Union

21 industry dummies (Source: Business Register by SF). (The sectoral variation of different types of M\&As is documented in Fig. 2.) 
The total number of establishments which were targets of mergers and acquisitions was 7289 over the period 1989-2003. Most of the establishments purchased were part of a domestic M\&A, with 4735 such cases. In total of these, 285 were such cases in which a purchaser is a domestic (i.e. located in Finland) but foreign-owned firm. The total number of cross-border M\&As was 765 during the same period. Hence, cross-border M\&As cover around $10 \%$ of all M\&As recorded in the magazine Talouselämä. This is a rather small share. The number of establishments that were targets in internal restructurings was 1789 over the period 1989-2003.

There is apparent variation in the volume of M\&As both across time and across sectors. (To compress the presentation in Figs. 1-2 all domestic M\&As are added together, i.e. domestic M\&As include M\&As both with a domestically-owned and a foreign-owned purchaser.) Fig. 1 documents the temporal variation in the number of M\&As. The large spike in the number of domestic M\&As in the year 1993 stems from the restructuring of the banking sector during the great depression of the early 1990s. Domestic M\&As were most widely spread in the Finnish Savings Banks Group. Interestingly, there has been a substantial increase in the number of cross-border M\&As during the latter part of the 1990s. The sectoral distribution of different types of M\&As is shown in Fig. 2. Crossborder M\&A activity has been most intensive in transport, the wholesale trade, and real estate, renting and business activities. These particular sectors cover around $60 \%$ of all cross-border M\&As during the period of 1989-2003. The difference in the incidence of cross-border M\&As between manufacturing and services is interesting, because most of the earlier papers have used data covering solely manufacturing. Domestic M\&As have been most common, by a wide margin, in finance and insurance, reflecting the structural change in this particular sector during the depression. 
Fig. 1. The number of different types of M\&As over the period 1989-2003. (Two types of domestic M\&As are added together.)

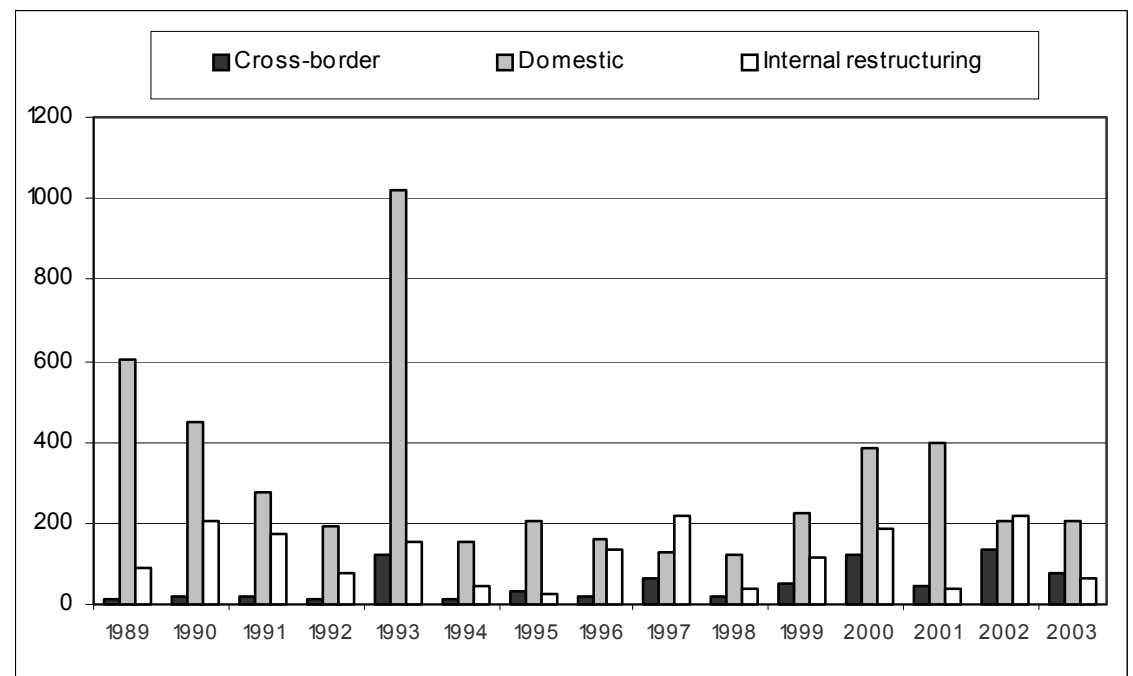

Fig. 2. The sectoral division of different types of M\&As. (The figures are reported as sums over the period 1989-2003 and two types of domestic M\&As are added together.)

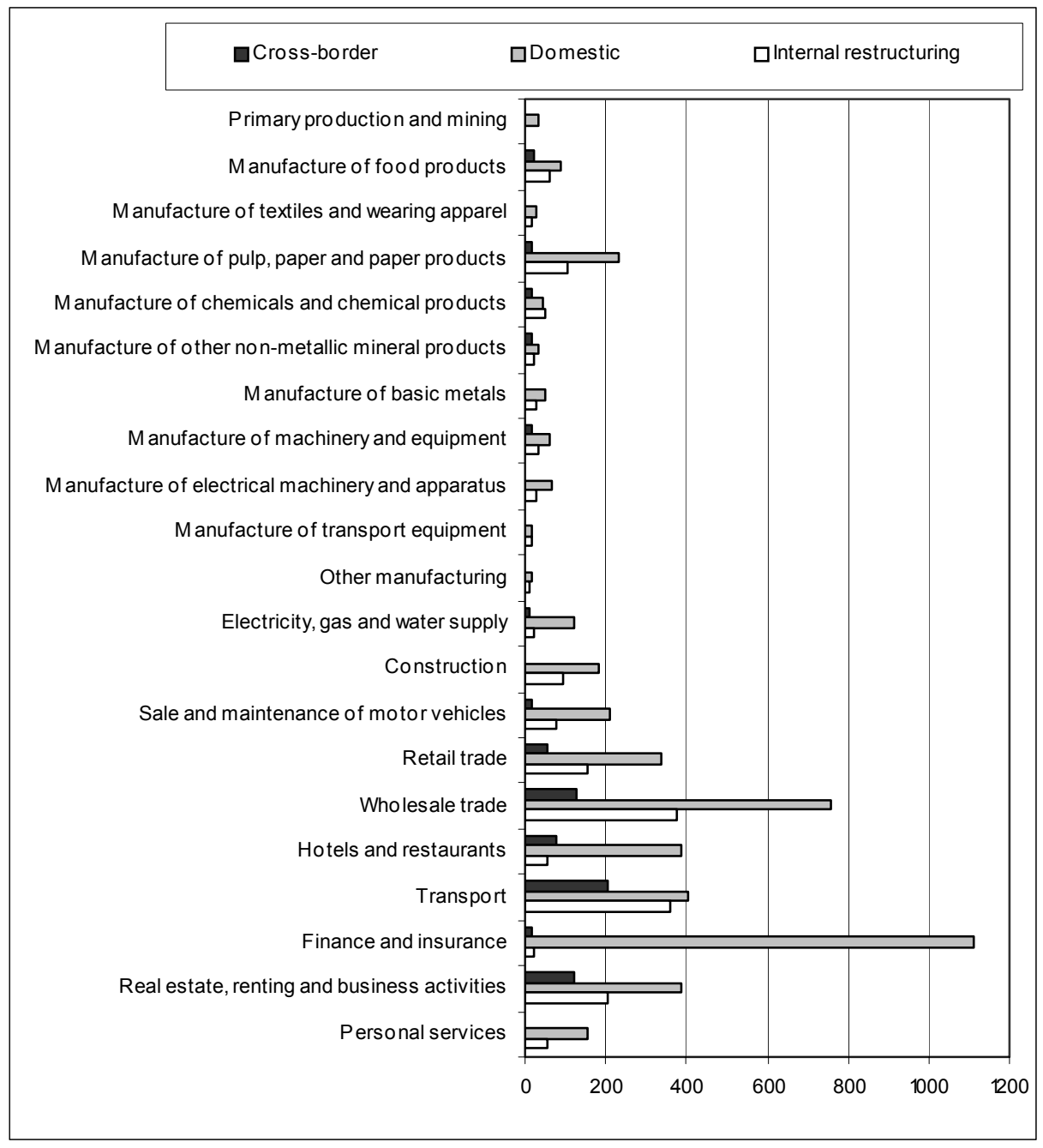


Matched data is assembled to obtain establishment-level variables that have a potential influence on the likelihood of being a target of M\&A and the evolution of employment after an incidence of M\&A. (The variables not self-explanatory are described in detail in Table 1.) Matching is made possible by the fact that the magazine Talouselämä lists the names of the companies that have been involved in M\&As. Hence, it is possible to manually link the firm codes to the names of the companies listed by the magazine. We have extensively used the trade register maintained by the National Board of Patents and Registration of Finland in this process. In addition, we have used the Business Register by Statistics Finland (SF). In particular, in complicated multi-plant mergers and acquisitions the additional information from the Business Register has been necessary to identify the parties of M\&A on the establishment level. The information about M\&As is linked to the Business Register by the use of the firm codes. Firms can further be linked to their establishments by the use of registers maintained by SF. Our variable of interest, employment, is obtained from the Business Register. Employment is measured as the average number of employees in the establishment over the year. This means that within-year changes do not cause problems in our analysis. In addition, the matched data is linked to Employment Statistics, also maintained by SF, which compiles information on the economic activity of individuals and their background characteristics (such as education). Employment Statistics contains an item of information (i.e. the plant code) on the employee's employer in the last week of each year. As a result, it is possible to link Employment Statistics to other data sources maintained by SF. In particular, the variables that capture the educational structure of the establishments involved originate from Employment Statistics.

\section{METHODOLOGY}

Distinct features of M\&As have notable implications for our modelling strategy. First and foremost, the selection of firms for targets is obviously an important issue in the context of M\&As. Foreign companies tend to take over certain Finnish companies with particular observable characteristics. Hence, the fundamental problem is that it is not possible to analyse the effect of M\&As on employment by the use of a random experiment in which there would be a lottery for being a target of M\&A. As a result, it is important to take into account the endogeneity of an M\&A decision when analysing 
the causal effect of M\&As on employment. From the theoretical perspective, it is possible to construct a hypothesis that older and larger domestic companies are more likely to be acquired by a company that is not located in the same country as the target company, because they are often listed in stock exchanges and there is more public information available about them, which makes a cross-border M\&A easier and less risky. The earlier empirical results on Finnish data (Lehto, 2006) show that foreign companies tend to take over firms whose workers' education level is high, whose size is large and who have some contact, for example exports, to foreign countries. Second, in addition to selection, it is equally important to recognise that the adjustment of employment is not immediate, at least in the manufacturing sector. For instance, Siljander (2005) provides some Finnish evidence on the substantial adjustment costs of employment by using firm-level data from 500 largest Finnish companies that mostly belong to manufacturing. For that reason, we look at the effects of M\&As on employment in time $\mathrm{t}+1$ and $\mathrm{t}+2$. The baseline for the employment level and for change in it is taken from $\mathrm{t}-1$. The reason for this is that by analysing the effect of M\&As on the employment level in time $\mathrm{t}-1$, we can check the validity of matching, because M\&As that occur in time $t$ should have no effect whatsoever on the employment level in $\mathrm{t}-1$. Because our employment variable is the average number of employees in the establishment during the year, the very first effects on employment can, in principle, seen in the year $\mathrm{t}$.

We estimate propensity score matching models when studying the effect of M\&As on employment. ${ }^{6}$ Propensity score matching aims to mimic a random experiment by constructing a control group from the group of untreated companies and to ensure that the control group is as similar as possible to the treatment group with respect to observable characteristics. In our case the treatment is a situation in which a firm has been a target of a particular type of M\&A. Matching has some distinct advantages over regression-based methods. First, matching does not impose any specific linearity assumptions on the evaluated effects that are present in regression-based modelling that is more commonly used in this field of research (e.g. Conyon et al. 2002b; Gugler and Yurtoglu, 2004). Second, matching explicitly addresses the so-called common support problem that finds for each untreated unit a similar treated unit. This is needed to

\footnotetext{
${ }^{6}$ Caliendo and Kopeinig (2005) provide a survey of these methods.
} 
construct the counterfactual mean that figures out what would happen to the treatment group without the treatment.

To construct a control group for firms that have been targets of M\&As over the period 1989-2003, we have included all domestic firms from the Business Register by SF that have a turnover of at least FIM 3 million (or around 510000 Euros). This is the very same limit that is used by the magazine Talouselämä when it reports M\&As. Because we analyse the effects of M\&As on employment in $t+1$ and $t+2$, we require that controls also have to exist in the Business Register by Statistics Finland in $t+1$ and $t+2$. The controls are always chosen from the set of firms who have not been a target in any kind of M\&A during time period $\mathrm{t}-1, \ldots, \mathrm{t}+2$. Our data allows us to make this exclusion as a result of which the results obtained describe, in a reliable way, the pure effect of the particular type of M\&A. For instance, we exclude those firms that have been subjects of domestic M\&As when analysing the effects of cross-border M\&As on employment.

Matching that is used to analyse the effect of different types of M\&As on employment can be conducted as follows. First, Probit models for being a subject of each type of M\&A were separately estimated in order to construct the control group. The establishment-level explanatory variables for the probability of observing each type of M\&A are shown in Table 1. (The results are not reported in order to save some space, but they are available upon request.) These prospensity scores give predictions for the likelihood of becoming a target of a particular type of M\&A. Propensity scores are used with the nearest-neighbour matching method when calculating the average treatment effect. We use the solely linear part of the prediction following Diamond and Sekhon (2005), because the compression of the probability mass around the value of zero and one could cause problems for matching.

Second, the employment level (or change in it) of those that have been a target of M\&A (i.e. the treatment group) was compared with the levels of those firms that have a similar prospensity (based on the predictions of Probit models) to be in the pool of firms taken over by other firm, but are not currently in the pool of those firms (i.e. the control group). After some experiments, we end up using in our analysis the program developed by Adadie et al. (2004) that was written for STATA in order to perform matching by the nearest-neighbour matching method and to calculate the corresponding average treatment effect on the treated. In the nearest-neighbour matching method one treated 
unit can be matched to more than one untreated unit. After looking at the robustness of the results, the number of controls was set to be five for each treated unit.

Hence, the effect of a particular type of M\&A on employment can be evaluated based on the average treatment effect. Let $\mathrm{Y}^{\mathrm{i}}(\mathrm{W})$ be the outcome variable $\mathrm{Y}$ of establishment $\mathrm{i}$. In our case the outcome variable is employment. $\mathrm{W}$ indicates whether establishment $\mathrm{i}$ has been a subject of M\&As. ( $\mathrm{W}$ is one when establishment $\mathrm{i}$ has been a subject of a particular type of M\&A; otherwise it is zero.) $\mathrm{M}^{\mathrm{i}}\left(\mathrm{Y}^{\mathrm{j}}(0)\right)$ indicates the average value of the outcome variable $\mathrm{Y}$ among the controls $\mathrm{j}$ that are chosen for the establishment $\mathrm{i}$ based on the predictions of Probit models. The average treatment effect for the treated that gives a quantitative magnitude for being a subject of a particular type of M\&A in terms of employment is calculated by using the equation

(1) $\quad \frac{1}{N^{I}} \sum_{i=0}^{N^{I}}\left[Y^{i}(1)-M^{i}\left(Y^{J}(0)\right)\right]$

where $\mathrm{N}^{\mathrm{I}}$ is the number of firms that have been targets of a particular type of M\&As. Time-invariant and industry-invariant unobservable factors, which have an asymmetric impact on the propensity score and on the outcome variable can cause some bias to the average treatment effect. For this reason and because there is a lot of variation in the volume of M\&As across years and industries (as documented in Figs. 1-2), we used the formula

$$
\frac{1}{N^{I}} \sum_{i=0}^{N^{I}}\left[Y_{t, s}^{i}(1)-M^{i}\left(Y_{t, s}^{J}(0)\right)\right]
$$

where $t$ is year and $s$ refers to industry level, in exact matching. Exact matching then ensures that the controls for the targets of different types of M\&As are selected from the same year and from the same industry. It scales down the amount of bias associated with time-invariant and industry-invariant unobservable factors.

In addition to the evaluation of different types of M\&As on the employment level, we estimate the average treatment effects for employment changes following Blundell et al. (2002) by using the formula 
(3) $\frac{1}{N^{I}} \sum_{i=0}^{N^{I}}\left[\left(Y_{t_{1}, s}^{i}(1)-Y_{t_{0}, s}^{i}(1)\right)-\left(M^{i}\left(Y_{t_{1}, s}^{J}(0)\right)-M^{i}\left(Y_{t_{0}, s}^{J}(0)\right)\right)\right]$,

where $t_{0}$ is time point before $\mathrm{M} \& \mathrm{~A}$ and $t_{1}$ is time point after M\&A. The underlying idea for this procedure is that difference-in-differences matching removes the fixed firm effects. The validity of the difference-in-differences estimator rests on common time effects across groups and no systematic composition changes within the treatment and the control group.

As noted in the earlier section, our analysis is done at the establishment level. However, some of our variables are measured at the firm level (firm's age and whether it is an exporter or not), because information on them is not available at the establishment level from the registers of SF. In the calculation of standard errors for these particular variables that are measured at the firm level we have taken into account, in the computation of standard errors, that observations are clustered by firms, because otherwise standard errors in them would be biased downwards. ${ }^{7}$

\section{THE RESULTS}

We present all our estimation results separately for manufacturing, construction and other services, and trade (including hotels and restaurants), because most of the earlier empirical evidence in this strand of the literature that was discussed in Section 2 of this paper is limited to manufacturing. (Primary production and electricity, gas and water supply from Fig. 2 are classified under manufacturing. "Trade (including hotels and restaurants)" includes sale and maintenance of motor vehicles, retail trade, wholesale trade, and hotels and restaurants from Fig. 2.) Non-manufacturing is further split into two separate sectors in order to obtain more detailed picture about the adjustment of employment in non-manufacturing.

We start by summarizing very briefly the most interesting estimation results that stem from the Probit models in which the likelihood of each type of M\&As is explained by establishment-level variables. (The results are not reported in order to save space, but they are available upon request.) The earlier results regarding these effects are reported

\footnotetext{
${ }^{7}$ Moulton (1990) has analysed this problem.
} 
and discussed in detail in Lehto and Lehtoranta (2004) and Lehto (2006). The models include indicators for a firm's legal form, industries, regions and years. The explanatory variables are reported in Table 1 and their values are taken from $t-1$. Depending on the particular type of M\&A and sector that we are analysing, the explanatory variables explain from 10 to 40 per cent of the total variation (measured by pseudo $\mathrm{R}^{2}$ ) in the dependent variable. The results reveal that cross-border M\&As are more likely to occur for large establishments. This applies to all sectors. There is evidence that exporters are more likely to be involved in cross-border M\&As. This effect is weakest in construction and other services. In general, a high share of highly educated employees seems to stimulate the likelihood of cross-border M\&As. Hence, foreign acquirers often target Finnish firms with a lot of accumulated knowledge embodied in human capital. Interestingly, a share of highly educated employees with technical qualifications does not have an effect on the likelihood of cross-border M\&As in construction and other services.

The results for domestic M\&As (both types) reveal that a firm's age is positively related to the likelihood of a domestic takeover. The reason for this is most likely that the age of a target firm is closely related to the available information for potential acquirers. Older firms are often listed and there is more public information available about them. The education structure plays a much smaller role in the determination of domestic M\&As (both types) compared with cross-border M\&As. As expected, an increase in a firm's age and an increase in the number of establishments tend to stimulate the likelihood of its internal restructuring. In addition, exporters are more likely to conduct internal restructurings. The most likely reason for this is that exporters may face more competition that makes them more inclined to conduct internal restructurings, which are often done in order to cut costs.

The results that emerge from the matching models on the effect of different types of M\&As on employment are summarized in Tables 2-5. They are reported as average treatment effects, in levels and in changes (based on the difference-in-differences estimator), respectively. The number of different types of M\&As is somewhat smaller with the use of matching models than in Figs. 1-2, because explaining the employment level in $\mathrm{t}+2$ means that we lose, by definition, three years of data $(1989,2002$ and 2003) and a surge of cross-border M\&As occurred towards the end of our observation period. In addition, the number of M\&As is reduced with the use of matching models owing to 
non-availability of the control variables for some establishments from the registers of SF. As expected, M\&As that occur in time $t$ have generally no statistically significant effect on employment level in t-1. This pattern emerges in all types of M\&As in all sectors (except from the model reported in column 2 in Table 3 and from the one in column 1 in Table 4). This supports the validity of matching. However, it is important to keep in mind that even when M\&As that occur in time $t$ have a statistically significant effect on the employment level in $\mathrm{t}-1$, the difference-in-differences estimator should give reliable results on the effects of different types of M\&As on the employment change in these cases.

The negative effects of cross-border M\&As for employment are evidently strongly present for manufacturing. For instance, for two years since being involved in a crossborder M\&A, the average annual level of employment has declined around $14 \%$ in an establishment in manufacturing (Table 2; Column 1). This is in line with the findings of earlier empirical studies (discussed in section 2 of this paper) that have mostly used data covering solely manufacturing. Interestingly, for other sectors (non-manufacturing) there is not much evidence of negative employment effects, but for construction and other services the results point out to a negative employment change two years since being involved in a cross-border M\&A. (For trade (including hotels and restaurants), there is even some indication of employment gains at the $10 \%$ significance level after one year from a cross-border M\&A.) 
Table 2. The effect of cross-border M\&As on the number of employees in the establishment.

\begin{tabular}{|l|l|l|l|}
\hline Response: & Manufacturing & $\begin{array}{l}\text { Construction and } \\
\text { other services }\end{array}$ & $\begin{array}{l}\text { Trade (hotels and } \\
\text { restaurants) }\end{array}$ \\
\hline Employment, $\mathrm{t}-1$ & & & \\
\hline SATT & -0.076 & 0.029 & -0.066 \\
\hline $\mathrm{z}$-value & -0.58 & 0.32 & -0.66 \\
\hline Employment, $\mathrm{t}$ & & & \\
\hline SATT & -0.188 & 0.024 & -0.088 \\
\hline $\mathrm{z}$-value & -1.41 & 0.23 & -0.85 \\
\hline Employment, $\mathrm{t}+1$ & & & \\
\hline SATT & $-0.260^{*}$ & -0.015 & 0.007 \\
\hline $\mathrm{z}$-value & -1.92 & -0.14 & 0.07 \\
\hline Employment, $\mathrm{t}+2$ & & & -0.067 \\
\hline SATT & $-0.144^{* *}$ & -0.130 & -0.65 \\
\hline $\mathrm{z}$-value & -2.15 & -1.16 & \\
\hline Employment, $\mathrm{t}-(\mathrm{t}-1)$ & & & -0.022 \\
\hline SATT & $-0.112^{* *}$ & -0.006 & -0.70 \\
\hline $\mathrm{z}$-value & -2.55 & -0.12 & \\
\hline Employment, $(\mathrm{t}+1)-(\mathrm{t}-1)$ & & & $0.073^{*}$ \\
\hline SATT & $-0.185^{* *}$ & -0.045 & 1.76 \\
\hline $\mathrm{z}$-value & -3.09 & -0.69 & \\
\hline Employment, $(\mathrm{t}+2)-(\mathrm{t}-1)$ & & & -0.001 \\
\hline SATT & $-0.233^{* *}$ & $-0.159^{* *}$ & -0.02 \\
\hline $\mathrm{z}$-value & -3.33 & -2.06 & 122 \\
\hline & & 97 & 111497 \\
\hline $\begin{array}{l}\text { The number of cross-border } \\
\text { M\&As }\end{array}$ & 59 & 118772 & \\
\hline The number of potential controls & 67656 & & \\
\hline
\end{tabular}

Notes: Robust z statistics are reported; * significant at $10 \% ;{ }^{* *}$ significant at $5 \%$. The number of controls is five in each case. SATT refers to average treatment effect

The results for the employment effects of domestic M\&As (with a domestically-owned acquirer) are substantially different from the ones that emerged for cross-border M\&As (Table 3). In particular, the results for domestic M\&As (with a domestically-owned acquirer) show that there are substantial negative (and statistically significant) employment effects for all sectors. This pattern is consistent with our hypothesis that in the service industries a domestic purchaser, being located in the same relevant market as the target firm, may have a greater interest than a foreign one to buy another firm in order to limit competition. Because the service market is often geographically restricted and because the joint use of assets (including human capital) may encounter geographical limits, we expected that in the service sectors the rationalisation through asset-sharing and the related downsizing of employment would be more typical of domestic M\&As (and internal restructuring) than of cross-border M\&As. Accordingly, cross-border M\&As have a larger negative effect on employment than domestic M\&As 
(with a domestically-owned purchaser) in the manufacturing sector. Overall, the quantitative magnitude of employment losses from domestic M\&As (with a domestically-owned purchaser) is quite similar to those reported by Gugler and Yurtoglu (2004), according to which European mergers and acquisitions reduce the demand for labour by about $10 \%$ on average. For instance, one year since being involved in a domestic M\&A (with a domestically-owned acquirer), the average annual level of employment has declined around $9 \%$ in an establishment in trade (including hotels and restaurants). In general, the negative employment effects of domestic M\&As (with a domestically-owned acquirer) are strongest for construction and other services. In particular, there is empirical evidence for around $20 \%$ decline in the employment level after two years of being a target of a domestic M\&A (with a domestically-owned purchaser).

Table 3. The effect of domestic M\&As (with domestically-owned purchasers) on the number of employees in the establishment.

\begin{tabular}{|l|l|l|l|}
\hline Response: & Manufacturing & $\begin{array}{l}\text { Construction and } \\
\text { other services }\end{array}$ & $\begin{array}{l}\text { Trade (hotels and } \\
\text { restaurants) }\end{array}$ \\
\hline Employment, $\mathrm{t}-1$ & & & \\
\hline SATT & -0.009 & $-0.107^{* *}$ & -0.033 \\
\hline z-value & -0.14 & -2.21 & -0.75 \\
\hline Employment, $\mathrm{t}$ & & & \\
\hline SATT & -0.042 & $-0.143^{* *}$ & $-0.080^{*}$ \\
\hline z-value & -0.64 & -2.85 & -1.80 \\
\hline Employment, $\mathrm{t}+1$ & & & \\
\hline SATT & -0.091 & $-0.192^{* *}$ & $-0.094^{* *}$ \\
\hline z-value & -1.35 & -3.64 & -2.09 \\
\hline Employment, $\mathrm{t}+2$ & & & \\
\hline SATT & $-0.117^{*}$ & $-0.203^{* *}$ & $-0.083^{*}$ \\
\hline z-value & -1.69 & -3.74 & -1.82 \\
\hline Employment, $\mathrm{t}-(\mathrm{t}-1)$ & & & \\
\hline SATT & $-0.034^{*}$ & $-0.036^{* *}$ & $-0.046^{* *}$ \\
\hline z-value & -1.89 & -2.06 & -3.41 \\
\hline Employment, $(\mathrm{t}+1)-(\mathrm{t}-1)$ & & & $-0.060^{* *}$ \\
\hline SATT & $-0.082^{* *}$ & $-0.085^{* *}$ & 3.18 \\
\hline z-value & -3.03 & -3.20 & \\
\hline Employment, $(\mathrm{t}+2)-(\mathrm{t}-1)$ & & & $-0.049^{* *}$ \\
\hline SATT & $-0.108^{* *}$ & $-0.097^{* *}$ & -2.23 \\
\hline z-value & -3.25 & -3.07 & \\
\hline & & & 770 \\
\hline The number of domestic M\&As & 340 & 540 & 227492 \\
\hline The number of potential controls & 90805 & 186719 & \\
\hline & & & \\
\hline
\end{tabular}

Notes: Robust z statistics are reported; * significant at $10 \%$; ** significant at $5 \%$. The number of controls is five in each case. SATT refers to average treatment effect. 
The results for the employment effects of domestic M\&As (with a foreign-owned acquirer) are reported in Table 4. At first sight, there are substantial employment gains (in levels) in the plant in the manufacturing sector after domestic M\&As (with a foreign-owned acquirer). However, M\&As that occur in time $t$ have a statistically significant effect on the employment level in $\mathrm{t}-1$ in this particular case, which casts serious doubts on the validity of matching. Indeed, the difference-in-differences estimator, which is reliable in this case, does not give support to the notion of employment gains (in changes). In addition, these particular results are based on a very small number of M\&As. In contrast, there are large negative employment effects in construction and other services, but in trade (hotels and restaurants) the effects are not statistically significant. Internal restructurings hurt employment, too (Table 5). Their effect is strongest in trade (including hotels and restaurants). To sum up, our estimation results covering non-manufacturing reveal that it is not solely cross-border M\&As that have statistically and economically significant, negative effects on employment. In general, almost all changes in ownership are associated with employment losses. 
Table 4. The effect of domestic M\&As (with foreign-owned purchasers) on the number of employees in the establishment.

\begin{tabular}{|l|l|l|l|}
\hline Response: & Manufacturing & $\begin{array}{l}\text { Construction and } \\
\text { other services }\end{array}$ & $\begin{array}{l}\text { Trade (hotels and } \\
\text { restaurants) }\end{array}$ \\
\hline Employment, $\mathrm{t}-1$ & & & \\
\hline SATT & $0.461^{* *}$ & -0.059 & 0.058 \\
\hline z-value & 1.99 & -0.35 & 0.26 \\
\hline Employment, $\mathrm{t}$ & & & \\
\hline SATT & $0.411^{*}$ & -0.113 & 0.015 \\
\hline z-value & 1.74 & -0.70 & 0.07 \\
\hline Employment, $\mathrm{t}+1$ & & & \\
\hline SATT & $0.499^{* *}$ & $-0.393^{* *}$ & -0.046 \\
\hline z-value & 2.04 & -2.10 & -0.18 \\
\hline Employment, $\mathrm{t}+2$ & & & \\
\hline SATT & 0.359 & $-0.378^{* *}$ & -0.103 \\
\hline z-value & 1.54 & -1.91 & -0.40 \\
\hline Employment, $\mathrm{t}-(\mathrm{t}-1)$ & & & \\
\hline SATT & -0.050 & 0.053 & -0.043 \\
\hline $\mathrm{z}$-value & -0.93 & -0.87 & -0.48 \\
\hline Employment, $(\mathrm{t}+1)-(\mathrm{t}-1)$ & & & \\
\hline SATT & 0.039 & $-0.333^{* *}$ & -0.104 \\
\hline z-value & 0.35 & 2.62 & -0.83 \\
\hline Employment, $(\mathrm{t}+2)-(\mathrm{t}-1)$ & & & \\
\hline SATT & -0.102 & $-0.319^{* *}$ & -0.161 \\
\hline z-value & -0.80 & -2.20 & -1.21 \\
\hline & & 51 & 23 \\
\hline The number of domestic M\&As & 35 & 125075 & \\
\hline The number of potential controls & 29440 & & \\
\hline & & & \\
\hline
\end{tabular}

Notes: Robust z statistics are reported; * significant at 10\%; ** significant at 5\%. The number of controls is five in each case. SATT refers to average treatment effect. 
Table 5. The effect of internal restructurings on the number of employees in the establishment.

\begin{tabular}{|l|l|l|l|}
\hline Response: & Manufacturing & $\begin{array}{l}\text { Construction and } \\
\text { other services }\end{array}$ & $\begin{array}{l}\text { Trade (hotels and } \\
\text { restaurants) }\end{array}$ \\
\hline Employment, $\mathrm{t}-1$ & & & \\
\hline SATT & -0.027 & -0.137 & -0.035 \\
\hline z-value & -0.34 & -1.60 & -0.53 \\
\hline Employment, $\mathrm{t}$ & & & \\
\hline SATT & -0.088 & -0.033 & -0.109 \\
\hline z-value & -1.11 & -0.35 & -1.61 \\
\hline Employment, $\mathrm{t}+1$ & & & \\
\hline SATT & -0.096 & -0.040 & $-0.116^{*}$ \\
\hline z-value & -1.16 & -0.41 & -1.70 \\
\hline Employment, $\mathrm{t}+2$ & & & \\
\hline SATT & -0.101 & -0.117 & $-0.186^{* *}$ \\
\hline z-value & -1.21 & -1.04 & -2.61 \\
\hline Employment, $\mathrm{t}-(\mathrm{t}-1)$ & & & \\
\hline SATT & $-0.061^{* *}$ & $0.104^{* *}$ & $-0.073^{* *}$ \\
\hline z-value & -2.81 & 1.96 & -3.46 \\
\hline Employment, $(\mathrm{t}+1)-(\mathrm{t}-1)$ & & & $-0.080^{* *}$ \\
\hline SATT & $-0.069^{* *}$ & 0.097 & 2.64 \\
\hline z-value & -2.26 & 1.62 & $-0.150^{* *}$ \\
\hline Employment, $(\mathrm{t}+2)-(\mathrm{t}-1)$ & & & -3.90 \\
\hline SATT & $-0.074^{*}$ & 0.020 & 219 \\
\hline z-value & -1.94 & 0.22 & 192711 \\
\hline & & 157969 & \\
\hline $\begin{array}{l}\text { The number of internal } \\
\text { restructurings M\&As }\end{array}$ & 226 & & \\
\hline The number of potential controls & 81475 & & \\
\hline & & & \\
\hline
\end{tabular}

Notes: Robust z statistics are reported; * significant at $10 \%$; $* *$ significant at $5 \%$. The number of controls is five in each case. SATT refers to average treatment effect.

\section{CONCLUSIONS}

This paper contributes to the literature by analysing the employment effects of different types of M\&As on target firms by using matched establishment-level data from Finland over the period of 1989-2003. In this paper, we do not focus solely on cross-border or domestic M\&As, but we analyse the employment effects of several different types of M\&As. We classify M\&As being either a cross-border M\&A (in which the purchaser is a foreign company that is located abroad), a domestic M\&A with a domestically-owned purchaser, a domestic M\&A with a foreign-owned company that is located in Finland or an internal restructuring in which the purchaser is not another company. Hence, in this classification "foreign" has a dual meaning: firstly, it refers to the distance between the acquirer and the target firm and, secondly, it specifies the nationality of an acquirer's 
owners from the target firm's viewpoint. Our data on M\&As covers all sectors. Most of the earlier literature has focused on manufacturing, instead.

We discover that cross-border M\&As lead to downsizing in manufacturing employment. The effects of cross-border M\&As on employment in non-manufacturing are much weaker. Domestic M\&As with a domestic purchaser, on the other hand, have negative employment effects for all sectors. The effect of domestic M\&As with foreignowned purchasers on employment is remarkably negative in construction and other services. Internal restructurings that do not involve another company also tend to cause employment losses. Taken together, our most important empirical finding is that almost all changes in ownership lead to employment losses. That cross-border M\&As had a negative impact only in manufacturing and that domestic M\&As with foreign-owned purchasers had, however, a substantial negative impact on employment in construction and other services may emerge from the situation in which foreign interference in service industries develops in two stages: first to establish a bridgehead through a crossborder M\&A, and after this to strengthen the dominance of the market through domestic M\&As. Apparently the deep-going rationalisation of activities is typical only of the latter stage, because deeper knowledge of the market has developed for a foreign player.

Our reading of the evidence is that the focus of the earlier empirical studies primarily on manufacturing (and listed companies) when analysing the employment effects of M\&As can deliver a seriously distorted picture about the adjustment of employment that takes place in broader industries. In particular, the negative effects of cross-border M\&As on employment are almost non-existent in non-manufacturing. In addition, the negative effects of M\&As on employment do not arise exclusively from cross-border M\&As. Hence, the evidence points out that cross-border M\&As seem to be less specific regarding their effects on employment than has previously been thought. A prominent explanation for employment losses is that the change in control through M\&As offers an opportunity for new management team to renege on implicit labour contracts that have constituted obstacles for layoffs (Shleifer and Summers, 1988). Our results call for more empirical studies that incorporate information from non-manufacturing sectors covering several different types of M\&As. 


\section{REFERENCES}

Abadie, A., Herr, J.L., Imbens, G.W., Drukker, D.M., 2004. NNMATCH: Stata module to compute nearest-neighbor bias-corrected estimators. Unpublished.

Bellak, C., 2004. How domestic and foreign firms differ and why does it matter? Journal of Economic Surveys 18, 483-514.

Bhagat, S., Shleifer, A., Vishny R.W., 1990. Hostile take-overs in the 1980s: the return of corporate specialization. Brookings Papers on Economic Activity: Microeconomics, $1-72$.

Blundell, R., Dias, M.C., Meghir, C., Van Reenen, J., 2002. Evaluating the employment impact of mandatory job search assistance program. The Institute for Fiscal Studies, WP01/20.

Brown, C., Medoff, J.L., 1988. The impact of foreign acquisition on labour. In: Auerbach, A. (Ed.): Corporate Takeovers: Causes and Consequences. University of Chicago Press, Chicago.

Caliendo, M., Kopeinig, S., 2005. Some practical guidance for the implementation of propensity score matching. IZA Discussion Paper No. 1588.

Conyon, M.J., Girma, S., Thompson, S., Wright, P.W., 2002a. The impact of mergers and acquisitions on company employment in the United Kingdom. European Economic Review 46, 31-49.

Conyon, M.J., Girma, S., Thompson, S., Wright, P.W., 2002b. Do hostile mergers destroy jobs? Journal of Economic Behaviour and Organization 45, 427-440.

Conyon, M.J., Girma, S., Thompson, S., Wright, P.W., 2002c. The productivity and wage effects of foreign acquisitions in the United Kingdom. The Journal of Industrial Economics 50, 85-102.

Diamond, A., Seklon, J.S., 2005. Generic matching for estimating causal effects: a general multivariate method for achieving balance in observational studies. Unpublished.

Farrell, J., Shapiro, C., 1990. Horizontal mergers: an equilibrium analysis. The American Economic Review 80, 107-126. 
Gugler, K., Yurtoglu, B.B., 2004. The effects of mergers on company employment in the USA and Europe. International Journal of Industrial Organization 22, 481-502.

Girma, S., Görg, H., 2004. Blessing or curse? Domestic plants' employment and survival prospects after foreign acquisition. Applied Economics Quarterly 50, 89-110.

Huttunen, K., 2006. The effect of foreign acquisition on employment and wages: evidence from Finnish manufacturing. The Review of Economics and Statistics, Forthcoming.

Ilmakunnas, P., Maliranta, M., 2004. Foreign medicine: a treatment effect analysis of the productivity effects of foreign ownership. Applied Economics Quarterly 50, 41-60.

Jensen, M., 1986. Agency costs of free cash flow, corporate finance and takeovers. The American Economic Review 76, 323-329.

Karpaty, P., 2005. Does foreign ownership matter? Multinational firms, productivity and spillovers. Örebro Studies in Economics, No. 8.

Lehto, E., 2006. Motives to restructure industries - Finnish evidence from cross-border and domestic mergers and acquisitions. Papers in Regional Science 85, 1-22.

Lehto, E., Lehtoranta, O., 2004. Becoming an acquirer and becoming acquired. Technological Change and Social Change 71, 635-650.

Lichtenberg, F.G., Siegel, S., 1990. The effect of ownership changes on the employment and wages of central office and other personnel. Journal of Law and Economics 33, $383-408$.

Lovio, R., 2004. The globalisation of Finnish corporations - similarities and differences in their current profiles. In: Ali-Yrkkö, J., Lovio, R. and Ylä-Anttila, P. (Eds.): Multinationals Enterprises in the Finnish Innovation System. Taloustieto Oy, Helsinki.

Malcomson, J.M., 1997. Contracts, hold-up, and labor markets. Journal of Economic Literature 35, 1916-1957.

Maliranta, M., 2005. Foreign-owned firms and productivity-enhancing restructuring in Finnish manufacturing industries. The Research Institute of the Finnish Economy, Discussion Paper No. 965.

Manne, H.G., 1965. Mergers and the market for corporate control. Journal of Political Economy 73, 110-120. 
Markusen, J., 2002. Multinational Firms and the Theory of International Trade. The MIT Press, Cambridge MA.

Marris, R., 1963. A model of the 'managerial enterprise'. Quarterly Journal of Economics 77, 185-209.

McGuckin, R.H., Nguyen, S.V., 2001. The impact of ownership changes: a view from labour markets. International Journal of Industrial Organization 19, 739-762.

McGuckin, R.H., Nguyen, S.V., Reznek, A.P., 1995. The impact of ownership change on employment, wages and labor productivity in US manufacturing 1977-1987. Center for Economic Studies, Washington D.C., US Bureau of Census, 95-8.

Moulton, B.R., 1990. An illustration of a pitfall in estimating the effects of aggregate variables on micro units. Review of Economics and Statistics, 72, 334-338.

Mueller, D.C., 2003. The finance literature on mergers: a critical survey. In: Waterson, M. (ed.): Competition, Monopoly and Corporate Governance: Essays in Honour of Keith Cowling. Cheltenham: Elgar.

Ollinger, M., Nguyen, S.V., Blayney, D.P., Chambers, B., Nelson, K., 2005. Effect of food industry mergers and acquisitions on employment and wages. United States Department of Agriculture, Economic Research Report No. 13.

Piscitello, L., Rabbiosi, L., 2002. Foreign entry through acquisition. The impact on labour productivity and employment. Unpublished, Politecnico de Milano.

Perry, M.K., Porter, R.H., 1985. Oligopoly and the incentive for horizontal merger. The American Economic Review 75, 219-227

Rossi, S., Volpin, P., 2003. Cross-country determinants of mergers and acquisitions. Unpublished, London School of Economics.

Salant, S.W., Switzer, S., Reynolds, R.J., 1983. Losses from horizontal merger: the effects of an exogenous change in industry structure on Cournot-Nash equilibrium. The Quarterly Journal of Economics 108, 185-199.

Schumpeter, J.S., 1934. The Theory of Economic Development. Harvard University Press, Cambridge, Massachusetts. 
Siegel, D.S., Simons, K.L., 2006. Assessing the effects of mergers and acquisitions on firm performance, plant productivity, and workers: New evidence from matched employer-employee data. Rensselaer Working Papers in Economics, No. 0601.

Siljander, E., 2005. Dynamic labour demand with heterogenous elasticity and adjustment. Unpublished, The Finnish Association of Graduate Engineers.

Shleifer, A., Summers, L., 1988. Breach of trust in hostile takeovers. In: Auerbach, A. (Ed.): Corporate Takeovers: Causes and Consequences. University of Chicago Press, Chicago. 